\title{
活性 岸トラップ
}

真空を报つていると、常にトラッブがついてまわる。 その大部分は寒剂を使つている。例えば、固型炭酸、或 いは固型篇酸とアルコール、液体空気等々。しかし、い ずれも大手が面到である上、たえず補給しなければ、ト ラップしたるのが 再蒸発してかえつて悪い影響を与え る。その上横位置には出来ないし、まして手の届かない 奥に取付けるわけには行かない。形も大きくなる。

ところが、活性炭であると、第一に補給の必要がなく て何回でも再生して使えるし、取付位置も自由だし、し かも脱ガスがスイッチーつで遠隔操作出来て大变便利だ といらことが判つたので、既に紹介された差動式ピラニ 型リークデクター(1)や真空度標準装置の排気系 ${ }^{(2)}$ に怹用 してみたのである。どのような場所に、どんな目的て使 つたかは末尾に記した交献を見ていただくとして、ここ では主に活性炭の入手法と処理について述べる。

使用し衣活性炭は、 activated charcoal と呼ばれて化 学用に市販されているものである。一般の市販品には粉 末 (powder) と粒状 (granular) の二種があり、粒状の

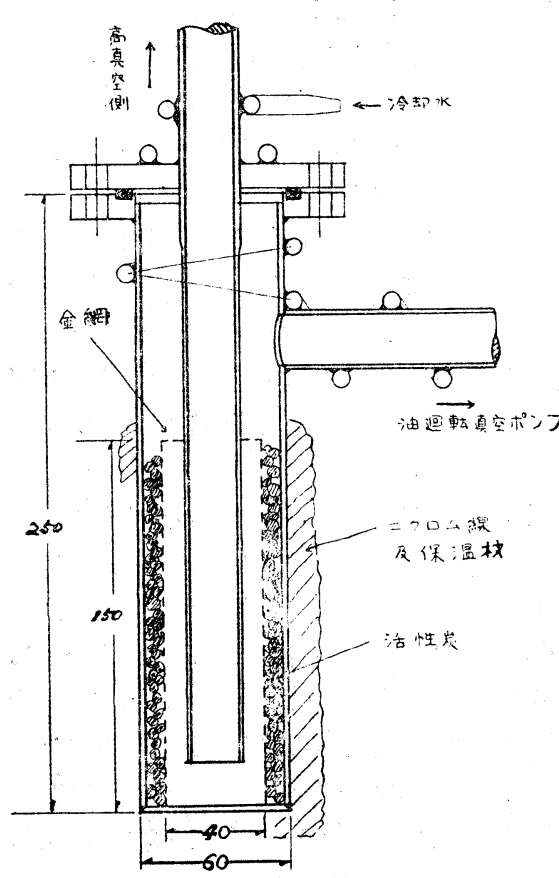

ネのにも 大粒の8 のや小粒 のものが あるから 注意する 必要があ る。排気 する時 に、飛散 したり排 気抵抗が 大くをな つたりす ろのは好 ましくな。 いので、 径 $3 \sim 4 \mathrm{~m}$ mのもの を選 ん だ。一見小豆ぐらいの大きさて、比較的粒がそろつてい
る。一級品とか特級品とかの区別はない上うで、だいた い1kg500円前後で簡単に入手出来る。

金属塩を吸着しているかも知れないので、新しい活性 炭は 2 規定位の稀塩酸で洗つた方がよい。蒸溜水でよく ゆすいでから、電気师で $150^{\circ} \mathrm{C}$ 位に加熱しながら迴転真 空ポンプで引いて脱水乾燥した。多量の水が出てくるか ら、予め考之て扔かなければいけない。冷之てから大気 中により出し、普通の薬ビンにつめて抵いて適宣使うこ とにしている。デシケーターのなかに納めておく必要は ない。

差動式ピラニ型リークデテクターの上うに配管の途中 に活性炭をつめてもよいし(交献 1参照)、コンダクタ ンスを考えて図のよろに管壁に並べても效果がある。金 網で動かないように抑える。固定し終つたら、排気して 加熱脱ガスする。外壁に絶縁してニクロム線を撩いて持 さ、250〜300 $\mathrm{C}$ 位に加熱すればよいが、大気中で加熱 することは避けなければいけない。

吸着能力は、詳しく測定した訳ではないので推定の域 を出ない。しかし真空度標準装置の場合、高真空側にあ つそ相当大きなもりにブタンガスをブローブしても低真 真空側で検出出来なかつたこと(水素では容易に検出さ れた）と、水銀拡散ポンプその他高真空側に何ら油の污 れが認められないことから、少くとも油廻転ポンブ油の 逆抆散をトラップする最初の目的は充分果されているも のと孝光られる。

差動式ピラニ型りーグデクターの場合、ガスの通り

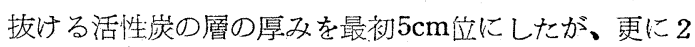
$\mathrm{cm}$ 位 (活性炭の粒子が 5 6 層位にあたる) のものも試 作してみている。一度の衝突で捕えられるとすれば、も つと少量でも済むと思われるが、吸着容量を考慮すれ ば、こんなものであろろ。

脱ガスのため加熱する時間は、吸着しているガス量と 加熱温度によるから、手まめに行えば、時間もかからず 簡単.である。真空度標準装置の場合一ケ月に一度 3 時間 位脱ガスする。大気にさらさなければ、この程度で充分 である。リークデテクターでは、感度をあげる意味か ら、使用する前に 30 分から 1 時間位脱ガスしている。
(1) 真空工業
(2) 真架工業
4 巻 6 号 177 頁
4 巻 2 号 61 頁

(電気試験所 中山勝 矢) 